Jurnal Info Kesehatan

Vol 17, No.1, Juni 2019, pp. 64-74

P-ISSN 0216-504X, E-ISSN 2620-536X

Journal DOI: https://doi.org/10.31965/infokes

Website: http://jurnal.poltekeskupang.ac.id/index.php/infokes

RES E A R C H

Open Access

\title{
N Terminal-Pro Brain Natriuretic Peptide (Nt-ProBNP) Pada Penderita Hipertensi Derajat 1 Dan Derajat 2
}

\author{
Supriati Wila Djami \\ Analis Kesehatan, Poltekkes Kemenkes \\ Kupang \\ Email: riatiputri85@gmail.com
}

\author{
Mansyur Arif; Uleng Bahrun \\ Fakultas Kedokteran, Universitas \\ Hasanuddin, Makassar \\ Email:mansyur_arief@yahoo.com; \\ ulengbahrun68@gmail.com
}

\begin{abstract}
Abstrak
Peningkatan kadar N Terminal-pro Brain Natriuretic Peptide (NT-proBNP) secara independen terkait dengan peningkatan risiko hipertensi. Penelitian ini bertujuan mengetahui perbedaan kadar NT-proBNP serum dan hubungan kadar NT-proBNP pada penderita Hipertensi Derajat 1 dan Derajat 2. Penelitian ini dilakukan di RSUP dr. Wahidin Sudirohusodo pada bulan Agustus -September 2018. Penelitian ini menggunakan desain cross sectional dengan jumlah pasien Hipertensi sebanyak 72 orang yang memenuhi kriteria inklusi.Kadar NT-proBNP diukur dengan menggunakan metoda ELISA (Enzyme Linked Immunosorbent Assay). Data yang terkumpul diolah dengan uji beda Mann Whithney, Spearman's rho.Hasil penelitian menunjukan kadar NT-proBNP pada penderita hipertensi derajat $2(172.85 \pm 316.26)$ lebih tinggi dan berbeda bermakna $(\mathrm{p}=<0,001)$ dibandingkan hipertensi derajat 1 (34.98 \pm 28.99$)$. Kadar NT-proBNP lebih tinggi pada kelompok penderita hipertensi $\geq 6$ tahun $(247.83 \pm 361.01)$ dibandingkan kelompok penderita hipertensi $<6$ tahun $(62.79 \pm 164.66)$, secara statistik ada perbedaan yang bermakna antara kedua kelompok tersebut $(\mathrm{p}=0,010)$. Disimpulkan bahwa tidak ada hubungaan yang bermakna kadar NTproBNP pada penderita hipertensi derajat 1 dan derajat $2(\mathrm{p}=0.862)$ walaupun menunjukan hasil berbeda bermakna.
\end{abstract}

Kata Kunci: NT-proBNP, Hipertensi, Derajat Hipertensi, Lama Hipertensi 


\title{
N Terminal-Pro Brain Natriuretic Peptide (Nt-Probnp) In Patients Hypertension Stage 1 And Stage 2
}

\begin{abstract}
The level of N Terminal - Pro Brain Natriuretic Peptide was independently associated with an increased risk of hypertension. This study aimed to determine the difference of NTproBNP serum levels and the correlation between the levels of NT-proBNP in patients with hypertension stage 1 and stage 2. This research was conducted at RSUP dr. Wahidin Sudirohusodo in August -September 2018. The research was conducted at Dr. Wahidin Sudirohusodo RSUP from August through September 2018. The study used a cross-sectional design with a total of 72 hypertensive patients, who had met the inclusive criteria. NTproBNP levels were measured using the ELISA (Enzyme-Linked Immunosorbent Assay) method. The collected data is processed using Mann Whitney Different Test and Spearman's rho Correlation Test. The study results indicated that the level of NT-proBNP in the hypertensive patients with stage $2(172.85 \pm 316.26)$ was higher and significantly different ( $p$ $=<0.001)$ compared to hypertensive patients stage $1(34.98 \pm 28.99)$. NT-proBNP levels were higher in the hypertensive group of $\geq 6$ years $(247.83 \pm 361.01)$ than in the hypertensive group $<6$ years $(62.79 \pm 164.66)$, statistically there were significant differences between the two groups $(\mathrm{p}=0.010)$. There was in a significant correlation between the levels of NT-proBNP in hypertensive patients, stage 1 and stage $2(p=0.862)$ even though it showed significantly different results.
\end{abstract}

Keywords: NT-proBNP, hypertension, degree of hypertension, duration of hypertension

\footnotetext{
*Correspondence: riatiputri85@gmail.com

Present Address: Kupang Kupang - Indonesia -

85111

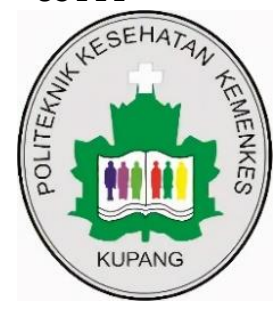

CThe Author(s) 2018. This article is distributed under the terms of the Creative Commons Attribution 4.0 International License (http://creativecommons.org/licenses/by/4.0/), which permits unrestricted use, distribution, and reproduction in any medium, provided you give appropriate credit to the original author(s) and the source, provide a link to the Creative Commons license, and indicate if changes were made. The Creative Commons Public Domain Dedication waiver (http://creativecommons.org/publicdomain/zero/1.0/) applies to the data made available in this article, unless otherwise stated.
} 


\section{PENDAHULUAN}

Hipertensi atau tekanan darah tinggi adalah masalah kesehatan global, termasuk di Indonesia karena prevalensinya tinggi, meskipun berbedabeda di berbagai negara.Hipertensi tidak memberikan keluhan dan gejala yang khas sehingga banyak penderita tidak menyadarinya, karena itu hipertensi dijuluki the silent killer atau "pembunuh diam-diam” (Rilantono, 2016). Hipertensi didefinisikan sebagai seseorang yang memiliki tekanan darah sistolik $\geqslant 140 \mathrm{mmHg}$ dan atau tekanan darah diastolik $\geqslant 90 \mathrm{mmHg}$, pada pemeriksaan yang berulang (Perki., 2015).

Data dari WHO (World Health Organization) pada tahun 2013 menunjukkan bahwa terdapat 9,4 juta orang dari 1 milyar penduduk di dunia yang meninggal akibat gangguan sistem kardiovaskular. Prevalensi hipertensi di negara maju sebesar 35\% dan di negara berkembang sebesar $40 \%$ dari populasi dewasa. Pada tahun 2025 diperkirakan kasus hipertensi terutama di negara berkembang akan mengalami peningkatan 80\% dari 639 juta kasus di tahun 2000, yaitu menjadi 1,15 milyar kasus. Prediksi ini didasarkan pada angka penderita hipertensi dan bertambahnya penduduk saat ini (WHO., 2013). Menurut hasil Riset Kesehatan Dasar (Riskesdas) tahun 2013, prevalensi hipertensi di Indonesia dengan responden pada umur 18 tahun keatas sebesar 25,8\% (Riskesdas., 2013).

Komplikasi hipertensi dapat mengenai berbagai organ seperti jantung (penyakit jantung iskemik, hipertrofi ventrikel kiri, gagal jantung), otak (stroke), ginjal (gagal ginjal), mata (retinopati) juga arteri perifer (klaudikasio intermiten).Kerusakan organ-organ tersebut bergantung pada tingginya tekanan darah pasien dan berapa lama tekanan darah tinggi tersebut tidak terkontrol dan tidak diobati (Muhadi, 2016). Adapun pembagian derajat keparahan hipertensi pada seseorang merupakan salah satu dasar penentuan tatalaksana hipertensi menurut The Sevent Report of The Joint National Commite on Prevention, Detection, Evaluation and Treatment of High Blood Pressure klasifikasi hipertensi pada orang dewasa dibagi menjadi kelompok normal, prehipertensi, hipertensi derajat I dan hipertensi derajat II(JNC VII., 2003). Tekanan darah sistolik merupakan pengukuran utama yang menjadi dasar penentuan diagnosis hipertensi (Perki., 2015).

$N$-Terminal-pro Brain Natriuretic Peptide (NT-proBNP) adalah hasil pemecahan hormon proBNP oleh enzim proteolitik furin yang disintesa dan disekresikan dari miosit jantung karena rangsangan batas daya tahan (stimulus stress) dinding jantung berupa regangan dinding ventrikel dan tekanan pengisian jantung yang ditimbulkan oleh berbagai 
penyebab (Renardi, 2009). Hipertensi merupakan salah satu faktor risiko utama penyakit kardiovaskuler, seperti gagal jantung, infark miokard bahkan kematian mendadak. Disamping digunakan sebagai petanda hayati (biomarker) untuk gagal jantung akut dan kronis, NT-proBNP juga dapat digunakan untuk mendeteksi penurunan fungsi ventrikel kiri penderita asimptomatik dengan faktor resiko kardiovaskuler (Asterina dkk., 2007).

Penelitian pada pasien kanker yang mendapat rejimen kemoterapi mengandung doksorubisin dapat mengalami efek samping kemoterapi pada jantung yang disebut kardiotoksisitas.Pemeriksaan NTproBNP dapat dipakai sebagai parameter baru untuk mengidentifikasi secara dini dan memantau perkembangan efek samping kemoterapi pada jantung, selain pengukuran fraksi ejeksi ventrikel kiri.Tujuan dari penelitian ini untuk mendapatkan perubahan nilai konsentrasi NT-proBNP dan fraksi ejeksi ventrikel kiri pada pasien kanker yang diberi rejimen kemoterapi mengandung doksorubisin siklus I - IV.hasil penelitian didapatkan peningkatan nilai median konsentrasi NT-proBNP dan penurunan rerata fraksi ejeksi ventrikel kiri pada pasien yang mendapat rejimen kemoterapi mengandung doksorubisin (Kamelia dkk., 2017).

Penelitian Renardi (2009), pada pasien gagal jantung untuk mengetahui hubungan nilai NT-proBNP pada penderita gagal jantung dan mengetahui apakah nilai NT-proBNP mempunyai hubungan dengan tingkat keparahan gagal jantung. Biomarker seperti NTproBNP telah diteliti sebagai uji yang dapat membantu diagnosis dan tatalaksana sekaligus prognosis gagal jantung. Penelitian Steffanus (2015), juga meyatakan bahwa ada hubungan antara peningkatan kadar NT-proBNP dengan penyakit sirosis hati.

Penelitian Asterina (2007), pada penderita penyakit jantung hipertensi mengatakan peningkatan kadar NTproBNP berhubungan dengan derajat penurunan fungsi jantung akibat hipertensi, adanya LVH tidak menimbulkan peningkatan kadar NTproBNP yang bermakna pada penderita hipertensi. Penelitian Khairunnisa (2017), menyatakan bahwa ada hubungan antara naiknya kadar NTproBNP dengan penurunan nilai fraksi ejeksi ventrikel kiri.NT-proBNP berbeda pada berbagai macam penyakit, karena itu perlu dilakukan penelitian lanjutan untuk mengetahui perbedaan kadar pada berbagai penyakit yang menyebabkan gagal jantung. Penelitian lain menyatakan bahwa peningkatan NTproBNP secara independen terkait dengan peningkatan risiko hipertensi (Bower et al., 2015). Hal ini yang membuat peneliti tertarik untuk mengetahui perbedaan kadar NT- 
proBNP dan hubungan kadar NT-ProBNP dengan derajat hipertensi.

\section{BAHAN DAN METODE}

\section{Lokasi dan Jenis Penelitian}

Penelitian ini dilaksanakan di Instalasi Rawat Jalan RSUP dr Wahidin Sudirohusodo (RSWS) Makassar, bulan Agustus - September 2018.Sampel yang terkumpul di analisis di Unit Penelitian FKUH/RSPTN

Universitas

Hasanuddin.Jenis penelitian ini merupakan penelitian cross-sectional.

\section{Populasi dan Sampel}

Populasi pada penelitian ini adalah semua pasien hipertensi yang menjalani rawat jalan di RSWS yang memiliki usia> 30 tahun dan menderita hipertensi derajat I dan derajat II serta memiliki tekanan darah sistolik $\geq 140$ mmHg dan tekanan darah diastolik $\geq 90$ mmHg.

\section{Analisis Data}

Data yang dikumpulkanberupa umur, jenis kelamin, lama hipertensi, tekanan darah,dan lain-lain dipaparkan dalam bentuk tabel untuk menjelaskan karakteristik sampel penelitian.Hasil pemeriksaan berupa Kadar NT-proBNP pada Penderita Hipertensi Derajat I dan Hipertensi Derajat II sebelumnya dilakukan uji Kolgomorov-Smirnov untuk mengetahui apakah data telah berdistribusi normal. Rerata dari kedua kelompok kemudian diuji untuk mengetahui signifikansinya dengan uji statistik Mann Whitney dan Korelasi Spearman's rho. Hasil dinyatakan bermakna bila nilai $P<0,05$.

\section{HASIL}

\section{Karakteristik Subjek Penelitian}

Tabel 1 menjelaskan bahwa pada penelitian ini berdasarkan karakteristik jenis kelamin subjek penelitian ini terdiri dari laki-laki sebanyak 32 pasien dengan persentase $44.4 \%$ dan perempuan sebanyak 40 pasien dengan persentase 55.6\%. berdasarkan karakteristik usia pada penelitian ini diperoleh data dengan usia kurang dari 45 tahun berjumlah 11 pasien dengan persentase $15.3 \%$ dan usia lebih dari atau sama dengan 45 tahun berjumlah 61 orang dengan persentase $84.7 \%$, sedangkan karakteristik pasien berdasarkan lamanya menderita hipertensi kurang dari 6 tahun berjumlah 56 pasien dengan persentase $77.8 \%$ dan lama hipertensi lebih dari atau sama dengan 6 tahun berjumlah 16 pasien dengan persentase $22.2 \%$. karakteristik berdasarkan tekanan darah pada penelitian ini diperoleh hipertensi derajat 1 sebanyak 36 pasien dengan persentase $50 \%$ dan hipertensi derajat 2 sebanyak 36 sampel dengan persentase $50 \%$.

Tabel 2 menunjukan rata-rata kadar NT-proBNP adalah $103.91 \mathrm{ng} / \mathrm{L}$, standar deviasi 233.53 , median 37.06 ng/L, kadar minimum $3.46 \mathrm{ng} / \mathrm{L}$ dan kadar maksimum $1252.65 \mathrm{ng} / \mathrm{L}$. Rata-rata umur pasien 56.17 tahun, standar deviasi 10.35 , median 56 tahun, umur minimum 
32 tahun dan umur maksimum 80 tahun. Rata-rata lama hipertensi yang diperoleh 2.64 tahun, standar deviasi 3.40, median 1 tahun, lama hipertensi minimum adalah 0 tahun (kurang dari satu tahun) dan lama hipertensi maksimum adalah 11 tahun. Rata-rata tekanan darah sistolik yang diperoleh $161.01 \mathrm{mmHg}$, standar deviasi 18.37, median 158.50 $\mathrm{mmHg}$, tekanan sistolik minimum 140 $\mathrm{mmHg}$ dan tekanan sistolik maksimum $220 \mathrm{mmHg}$ sedangkan rata-rata tekanan darah diastolik yang diperoleh 98.15 mmHg, standar deviasi 7.84, median 99 $\mathrm{mmHg}$, tekanan diastolik minimum 140 $\mathrm{mmHg}$ dan tekanan diastolik maksimum $121 \mathrm{mmHg}$.

\section{Analisis Kadar \\ NT-proBNP \\ Berdasarkan Karakteristik Subjek Penelitian}

Pada penelitian ini dilakukan analisis untuk mengetahui keterkaitan antara kadar NT-proBNP dengan beberapa karakteristik pasien menggunakan beberapa uji statistik meliputi Uji Kolmogrov-Smirnov, Shapiro -Wilk, Mann Whitney dan Uji Korelasi Spearman's rho. Hasil analisis statistik berdasarkan karakteristik subjek penelitian memperlihatkan adanya perbedaan yang bermakna pada kadar NT-proBNP yaitu berdasarkan lama pasien menderita hipertensi dan derajat hipertensi.

Hasil analisis statistik pada Tabel 3 pada penelitian ini menunjukkan umur rata-rata subjek dalam penelitian ini adalah $56.17 \pm 10.35$ tahun dengan umur terbanyak adalah $\geq 45$ tahun sebesar 84.7\%, setelah dilakukan uji beda berdasarkan karakteristik umur pasien dengan kadar NT-proBNP nilai $\mathrm{p}=0.863$ $(>0,05)$. Hasil uji statistik menunjukan terdapat perbedaan yang bermakna antara kadar NT-proBNP pada pasien Hipertensi Derajat 1 dan Derajat 2. Kadar NT-proBNP berdasarkan karakteristik tekanan darah sistolik 140-159 mmHg; diastolik 90-99 $\mathrm{mmHg}$ (Hipertensi Derajat 1) dan Tekanan darah sistolik $\geqslant 160 \mathrm{mmHg}$; diastole $\geqslant 100 \mathrm{mmHg}$ (Hipertensi Derajat 2) setelah dilakukan uji beda secara statistik nilai $\mathrm{p}=<0,001$ $(p=<0,05)$.

Hasil analisis statistik pada Tabel 4 berdasarkan karakteristik subjek penelitian memperlihatkan tidak adanya korelasi dengan kadar NT-proBNP setelah dilakukan uji korelasi Spearman's rho tidak diperoleh nilai significancy $(\mathrm{p}<0,05)$ sehingga dapat disimpulkan tidak ada hubungan yang bermaka antara kadar NT-proBNP dengan derajat hipertensi.

\section{PEMBAHASAN}

Penelitian ini menunjukan pasien penderita hipetertensi pada perempuan lebih banyak dari laki-laki dan usia $\geq 45$ tahun lebih banyak dari usia $<45$ tahun. Menurut Azhar (2017) mengatakan bahwa hipertensi lebih banyak 
menyerang perempuan dibandingkan laki-laki.Hal ini terjadi karena perempuan yang belum menopause dilindungi oleh hormon esterogen yang dapat meningkatkan konsentrasi HDL dan menurunkan konsentrasi LDL. Akan tetapi setelah perempuan mengalami masa menopouse, hormon esterogen akan mengalami penurunan. Terutama dialami oleh perempuan yang sudah usia lanjut, sehingga tekanan darah pada perempuan lanjut usia cenderung tinggi (Azhar, 2017).

Pada penelitian ini rata-rata kadar NT-proBNP pada laki-laki adalah $51.49 \pm 48.51 \mathrm{ng} / \mathrm{L}$ dan pada wanita $145.86 \pm 305.55 \mathrm{ng} / \mathrm{L}$, setelah dilakukan uji beda secara statistik nilai $\mathrm{p}=0,803$ $(p=>0,05)$ sehingga disimpulkan tidak ada perbedaan kadar NT-proBNP yang bermakna pada laki-laki dan perempuan. Hasil ini sesuai dengan penelitian Renardi (2009) menunjukkan tidak terdapat perbedaan bermakna diantara kelompok jenis kelamin dimana pada penelitian Renardi peningkatan kadar NT-proBNP yang lebih tinggi pada pria dibandingkan wanita sedangkan pada penelitian ini kadar NT-proBNP lebih tinggi pada wanita dari pada laki-laki. Pertentangan ini dapat dipahami karena menggunakan jumlah sampel yang berbeda dan distribusi yang tidak merata pada kedua kelompok hipertensi.

Hasil penelitian lain menunjukan bahwa perempuan dan laki-laki memiliki konsentrasi NT-proBNP yang relatif sama. Konsentrasi NT-proBNP bervariasi, tergantung pada jenis kelamin dan usia. Pada laki-laki, konsentrasi NTproBNP meningkat sesuai dengan usia demikian juga dengan perempuan konsentrasi plasma NT-proBNP relatif meningkat sesuai dengan usia (Karmelia, 2017).

Penelitian ini menunjukkan umur rata-rata subjek dalam penelitian ini adalah $56.17 \pm 10.35$ tahun dengan umur terbanyak adalah $\geq 45$ tahun sebesar 84.7\%, setelah dilakukan uji beda berdasarkan karakteristik umur pasien dengan kadar NT-proBNP nilai $\mathrm{p}=0.863$ $(>0,05)$ atau dengan kata lain tidak terdapat perbedaan yang bermakna antara umur dengan kadar NT-proBNP. Berbeda dengan hasil penelitian ini, Sarzani et al (2016), dengan rata-rata umur subjek penelitiannya yaitu $88.1 \pm 5.1$ tahun menyimpulkan terdapat perbedaan yang bermakna antara faktor usia dengan NT-proBNP pada pasien Heart Failure. Pertentangan ini dapat dipahami karena penelitian dilakukan pada kelompok usia yang berbeda dan kelompok kasus yang berbeda.

Rata-rata kadar NT-proBNP berdasarkan karakteristik lama pasien menderita hipertensi $<6$ tahun adalah $62.79 \pm 164.66 \mathrm{ng} / \mathrm{L}$ dan $\geq 6$ tahun $247.83 \pm 361.01 \mathrm{ng} / \mathrm{L}$, setelah dilakukan uji beda secara statistik nilai $\mathrm{p}=0,010$ $(\mathrm{p}=<0,05)$ sehingga disimpulkan ada perbedaan kadar NT-proBNP yang bermakna berdasarkan karakteristik lama hipertensi. Hasil ini tidak sejalan dengan penelitian Munir \& Sargowo (2010) 
menunjukkan tidak terdapat perbedaan bermakna berdasarkan durasi hipertensi (lama hipertensi) dengan nilai $\mathrm{p}=0,593$ $(p=>0,05)$. Perbedaan penelitian ini dapat dipahami karena menggunakan sampel dengan rata-rata lama hipertensi yang berbeda, penelitian ini dengan rata-rata lama hipertensi 2.64 \pm 3.40 sedangkan Munir dan Sargowo menggunakan ratarata lama hipertensi $5.66 \pm 4.63$ dan juga dapat disebabkan karna distribusi yang tidak merata pada kedua kelompok hipertensi.

Hasil uji statistik yang dilakukan disimpulkan terdapat perbedaan yang bermakna antara kadar NT-proBNP pada pasien Hipertensi Derajat 1 dan Derajat 2. Kadar NT-proBNP berdasarkan karakteristik tekanan darah sistolik 140$159 \mathrm{mmHg}$; diastolik 90-99 $\mathrm{mmHg}$ (Hipertensi Derajat 1) dan Tekanan darah sistolik $\geqslant 160 \mathrm{mmHg}$; diastole $\geqslant 100 \mathrm{mmHg}$ (Hipertensi Derajat 2) setelah dilakukan uji beda secara statistik nilai $\mathrm{p}=<0,001$ $(p=<0,05)$. Hal ini tidak sejalan dengan pengamatan Munir \& Sargowo (2010), yang menyimpulkan tidak terdapat perbedaan yang signifikan kadar NTproBNP pada pasien penderita hipertensi dengan LVH. Pertentangan ini dapat dipahami karena penelitian dilakukan dengan jumlah sampel yang berbeda dan kelompok kasus yang berbeda. Kesepakatan penelitian ini dapat disimpulkan kadar NT-proBNP lebih tinggi pada Hipertensi Derajat 2 dengan nilai rata-rata kadar NT-proBNP sebesar 172.85 \pm 316.26 ng/L sedangkan pada Hipertensi Derajat 1 yang kadarnya lebih rendah dengan nilai rata-rata $34.98 \pm 28.99 \mathrm{ng} / \mathrm{L}$.

Rata-rata kadar NT-proBNP pada laki-laki adalah 51.49 $\pm 48.51 \mathrm{ng} / \mathrm{L}$ dan pada wanita $145.86 \pm 305.55 \mathrm{ng} / \mathrm{L}$, setelah dilakukan uji korelasi spearmen's rho secara statistik nilai significancy 0,762 $(\mathrm{p}=>0,05)$ sehingga disimpulkan tidak ada korelasi atau hubungan kadar NTproBNP yang bermakna pada laki-laki dan perempuan. Hasil ini sesuai dengan penelitian Rosello et al (2012) menunjukkan tidak terdapat hubungan yang bermakna berdasarkan karakteristik jenis kelamin pada pasien hipertensi. Rata-rata kadar NT-proBNP berdasarkan umur pasien $<45$ tahun adalah $46.77 \pm 35.10 \mathrm{ng} / \mathrm{L}$ sedangkan kadar NTproBNP pada umur $\geq 45$ adalah $114.22 \pm 252.24 \mathrm{ng} / \mathrm{L}$, setelah dilakukan uji korelasi antara umur dengan kadar NTproBNP nilai $p=0.979 \quad(p=>0,05)$ atau dengan kata lain tidak terdapat hubungan yang bermakna antara umur dengan kadar NT-proBNP. Hasil ini sesuai dengan penelitian Renaldi (2013), menunjukkan secara statistik tidak terdapat korelasi yang bermakna untuk nilai kadar NT-proBNP berdasarkan karakteristik umur pada pasien penderita gagal jantung.

Rata-rata kadar NT-proBNP berdasarkan karakteristik lama pasien 
menderita hipertensi $<6$ tahun adalah $62.79 \pm 164.66 \mathrm{ng} / \mathrm{L}$ dan $\geq 6$ tahun $247.83 \pm 361.01 \mathrm{ng} / \mathrm{L}$, setelah dilakukan uji korelasi secara statistik nilai $\mathrm{p}=0,189$ $(\mathrm{p}=>0,05)$ sehingga disimpulkan tidak ada korelasi antara kadar NT-proBNP yang bermakna dengan lama hipertensi. Hasil penelitian ini secara statitik sesuai dengan penelitian Munir \& Sargowo (2010), menunjukkan tidak terdapat korelasi bermakna antara kadar NTproBNP dengan durasi hipertensi (lama hipertensi) pada penderita hipertensi.

Hasil uji statistik yang telah dilakukan dapat disimpulkan tidak terdapat korelasi yang bermakna antara kadar NT-proBNP pada pasien Hipertensi Derajat 1 dan Derajat 2. Kadar NTproBNP berdasarkan karakteristik tekanan darah sistolik 140-159 mmHg; diastolik 90-99 mmHg (Hipertensi Derajat 1) dan Tekanan darah sistolik $\geqslant 160 \mathrm{mmHg}$; diastole $\geqslant 100 \mathrm{mmHg}$ (Hipertensi Derajat 2), setelah dilakukan uji korelasi secara statistik nilai $\mathrm{p}=0,862$ $(p=>0,05)$. Hal ini sesuai dengan pengamatan Asterina dkk (2007) yang juga menyimpulkan tidak terdapat hubungan yang signifikan antara kadar NT-proBNP pada pasien penderita penyakit jantung hipertensi. Kesepakatan penelitian ini dapat disimpulkan tidak ada hubungan yang bermakna antara kadar NT-proBNP dengan Derajat Hipertensi.

\section{KESIMPULAN DAN SARAN}

Kami menyimpulkan bahwa terdapat perbedaan bermakna kadar NTproBNP dengan derajat hipertensi, ditemukan kadar NT-proBNP yang lebih tinggi pada penderita hipertensi derajat 2 dibandingkan kelompok hipertensi derajat 1 walaupun secara statistik tidak terdapat hubungan yang bermakna antara kadar NT-proBNP dengan derajat hipertensi.Perlu dilakukan penelitian lanjutan untuk mengetahui hubungan kadar NT-proBNP dengan derajat hipertensi, sehingga dapat mempertegas diagnosa terutama pada pasien hipertensi dan perlu diperhatikan keakuratan data lamanya pasien menderita/terdiagnosa hipertensi sehingga dapat menghilangkan bias.

\section{DAFTAR PUSTAKA}

Asterina, F., Nasution, B. \& Akbar, N. (2007). The Level of $\mathrm{N}$ Terminal-Pro Brain Natriuretic Peptide in Hypertensive Heart Disease Patients.Indonesian Journal of Clinical Pathology and Medical Laboratory.Vol 14 No 1: 42 46.

Azhar, I. (2017). Gambaran Karakteristik Pasien Hipertensi di Puskesmas Gamping Sleman Yogyakarta.Yogyakarta: Sekolah Tinggi Ilmu Kesehatan Universitas Jenderal Achmad Yani Yogyakarta.

Bower et al., (2015). N-Terminal Pro-Brain Natriuretic Peptide (NT-proBNP) and 
Risk of Hypertension in the Atherosclerosis Risk in Communities

(ARIC) Study.American Journal of Hypertension. 28(10): 1262 - 1266.

Joint National Committee (JNC) VII. (2003).

The Sevent Report of The Joint National

Committee on Prevention, Detection, Evaluation, and Treatment of High

Blood Pressure. U.S: Department of

Health And Human Services.

Karmelia T., Waspadji S., Makmun L. H.,

Effendi S., Ramli M. \& Timan I.S.

(2017). Perubahan Konsentrasi

Amino Terminal Pro B-Type

Natriuretic Peptide (NT-proBNP) dan

Fraksi Ejeksi Ventrikel Kiri pada

Pasien

Kemoterapi

Doksorubisin.Jurnal Penyakit Dalam Indonesia. 4(2): 78 - 82.

Khairunnisa. (2017). Korelasi Kadar NT proBNP dengan Fungsi Fraksi Ejeksi Ventrikel Kiri pada Gagal Jantung Anak. Padang: Program Pasca Sarjana Ilmu Biomedik - Program Pendidikan Dokter Spesialis FK UNAND - RS.M. DJAMIL.

Muhadi. (2016). JNC 8: Evidence-based Guideline. Penanganan Pasien Hipertensi Dewasa, (Online), Vol. 43, No.1,
(www.cdkjournal.com/index.php/CD

K/article/, diakses 14 Januari 2018).

Munir, A. \& Sargowo, N. (2010).N TerminalPro Brain Natriuretic Peptide as Indicator of Left Ventricle Hypertropy In Hypertensive Patients Compared with Left Ventricle Mass Index in Echocardiography. Jurnal Kardiologi Indonesia.Vol 31 No 2: 87 98.

Perhimpunan Dokter Spesialis Kardiovaskular Indonesia (Perki).(2015). Pedoman Tatalaksana Hipertensi pada Penyakit Kardiovaskular. Edisi I. Jakarta: Perhimpunan Dokter Spesialis Kardiovaskular Indonesia.

Renardi, T. R. (2009). Hubungan Nilai $N$ Terminal Pro-Brain Natriuretic Peptide (NT-proBNP) dengan Keparahan Penderita Gagal Jantung. Medan: Departemen Ilmu Penyakit Dalam Fakultas Kedokteran Universitas Sumatera Utara.

Rilantono, L.I. (2016). Penyakit Kardiovaskular. Jakarta: Fakultas Kedokteran Universitas Indonesia.

Riset Kesehatan Dasar (RISKESDAS). (2013). Badan Penelitian dan Pengembangan 
Kesehatan. Jakarta: Kementerian Stefannus, M. (2015). Hubungan Positif

Kesehatan RI.

Rosello et al., (2012). Variability of NTproBNP and Its Relationship with Inflammatory Status in Patients with Stable Essential Hypertension.PLOS Journals.Vol 7 No 1.

Sarzani, R. et al (2016). NT-proBNP and Its Correlation Hospital Mortality in the Very Elderly without and Admission Diagnosis of Heart Failue.PLOS Journals. Vol 10 No 1371.
Antara Derajat Penyakit Sirosis Hati dengan $N$ Terminal - pro Brain Natriuretic Peptide (NT-proBNP) pada Sirosis Hati. Denpasar: Program Magister Ilmu Biomedik Universitas UDAYANA.

World Health Organization (WHO). (2013). Calls for Intensiified Efforts to Prevent and Control Hypertension, (Online), ( $\quad$ http://www.who.int/ workforcealiance/media/news/, diakses 16 Februari 2018).

Ready to submit your research? Choose INFOKES and benefit from:

- fast, convenient online submission

- $\quad$ thorough peer review by experienced researchers in your field

- rapid publication on acceptance

- $\quad$ support for research data

- Open Access which fosters wider collaboration and increased citations

- maximum visibility for your research

At Health Polytechnic of Kupang, research is always in progress.

Learn more http://jurnal.poltekkekupang.ac.id/index.php/infokes 